-Author(s)

\section{Pacheco $\mathrm{BHC}^{\prime}$}

Nakagi VS'

Kobashigawa $\mathrm{EH}$

Caniatto ARM'

Faria $D E^{\prime}$

Pacheco $\mathrm{BHC}^{\prime}$

Faria Filho DE

Faculdade de Zootecnia e Engenharia de Alimentos - Zootecnia/USP

\section{ABSTRACT}

The objective of this study was to determine the optimal dietary concentration of zinc and manganese on the performance characteristic and the requirement of these trace minerals derived from organic sources for broilers from 1 to 42 days of age. In experiment 1, zinc was evaluated, whereas manganese was evaluated in experiment 2 . In each experiment, 320 males chicks were distributed in iron mesh metabolic cages $(0.9 \mathrm{~m} \times 0.7 \mathrm{~m} \times 0.5 \mathrm{~m})$, according to a completely randomized experimental design in eight treatments with five replicates of eight birds each. In experiment 1, zinc sulfate was included at 0,60 and $100 \mathrm{mg} / \mathrm{kg}$ and zinc methionine at 20,40,60, 80 and $100 \mathrm{mg} / \mathrm{kg}$. In experiment 2, manganese sulfate was added at 0,65 and $105 \mathrm{mg} / \mathrm{kg}$ and manganese methionine at 25, 45, 65, 85 and $105 \mathrm{mg} / \mathrm{kg}$. Trace mineral requirements were determined comparing only organic trace mineral levels. The evaluated trace minerals (zinc and manganese) did not influence broiler performance, independently of source or level. It was concluded that the requirements of broilers from 1 to 42 days of age were supplied with no addition of zinc or manganese, under the conditions of the present experiments. However, under commercial rearing conditions, which are more challenging, the use of levels higher than $33.00 \mathrm{mg} / \mathrm{kg}$ and $37.80 \mathrm{mg} / \mathrm{kg}$ of zinc and manganese, respectively, may be justified.

\section{INTRODUCTION}

There has been extensive research on organic trace minerals, as they have higher bioavailability and are stored longer in the body than their inorganic counterparts (Kiefer, 2005). The nutritional requirements of broilers vary according to sex and rearing phase, and are typically reduced with age. This also applies to trace minerals, and it is important to perform studies to determine their precise requirements for optimal bird development, thereby preventing the supply of excessive amounts, which may cause environmental pollution and result in additional costs (Gomes et al., 2009).

The efficacy of the use of micro elements is an important issue in modern poultry nutrition. Micro elements are essential for normal growth and many metabolic processes in living organisms, as they are catalysts or constituents of the enzymatic systems of many cells. The availability of minerals from feed materials of plant origin, as well as from traditional inorganic sources, i.e., oxides, sulphates, or carbonates, is relatively low, while the requirements of modern broiler chickens for microelements are very high (Aksu et al., 2012).

The results of some recently published original research works demonstrate that organic forms of trace elements provide protection against the creation of indigestible complexes with some anti-nutritive dietary compounds in the intestine and against reciprocal mineral 
Faria Filho DE, Nakagi VS,

Kobashigawa EH, Caniatto ARM,

Faria DE, Pacheco BHC
Dietary Levels of Zinc and Manganese on the

Performance of Broilers Between 1 to 42 Days of Age antagonisms. In addition, they offer an alternative, much more effective method of absorption and may have higher availability as a source of micro elements for birds (Świątkiewicz et al., 2014).

Modern broiler chickens have undergone considerable genetic transformation necessitating reevaluation of mineral requirements in the context of higher growth rate, skeletal demands and immune response (Suttle, 2010; Sunder et al., 2013). Each of these criteria responded differently to $\mathrm{Zn}$ and $\mathrm{Mn}$ levels in diets, suggesting the existence of variability in mineral requirements for individual parameters (Sunder et al., 2006; Sunder et al., 2013).

Considering the importance of manganese and zinc and the still controversial literature results on the use of chelated trace minerals, the present study aimed at determining dietary zinc and manganese concentrations required to promote optimal performance, as well as the requirements of these trace minerals in a chelated form for broilers from 1 to 42 days of age.

\section{MATERIALS AND METHODS}

Two experiments were carried out at Poultry Laboratory of Faculty of Animal Science and Food Engineering (FZEA), University of São Paulo, Campus of Pirassununga. In each experiment was used 320 Cobb500 ${ }^{\mathrm{TM}}$ broilers from 1 to 42 days of age, and birds were distributed in to 40 iron-mesh metabolic cages $(0.9 \mathrm{~m} \times 0.7 \mathrm{~m} \times 0.5 \mathrm{~m})$, each equipped with a nipple drinker, featuring trough feeders, and a tray under the cage for excreta collection. Each cage (experimental unit) housed eight birds until day 21, and six birds thereafter, i.e., until day 42.

Experiment 1 (Table 1) and experiment 2 (Table $2)$, were based on corn and soybean meal. The experimental diets were supplemented with the tested trace minerals and were formulated according to the recommendations of Rostagno et al. (2005). The experimental minerals were zinc or manganese levels and sources (organic or inorganic) in isoproteic and isocaloric diets in each rearing phase.

In each experiment, chicks were distributed according to a completely randomized experimental design into eight treatments with five replicates of eight birds each. In experiment 1, treatments consisted of the addition of increasing levels of zinc sulfate (ZnSO4, containing 35\% Zn - Inorganic Zn) or zinc methionine (Zinpro ${ }^{\circledR}$, containing $10 \% \mathrm{Zn}$ - Organic $\mathrm{Zn)}$, as shown in Table 3. In experiment 2, treatments consisted of the addition of increasing levels of manganese sulfate (MnSO4, containing 31\% Mn-
Table 1 - Ingredient composition of the experimental diets for the phases from 1 to 21 and from 22 to 42 days of age, without zinc supplementation (Experiment 1).

\begin{tabular}{|c|c|c|}
\hline \multirow[t]{2}{*}{ Ingredients } & \multicolumn{2}{|c|}{ Experimental phase (days) } \\
\hline & $1-21$ & $22-42$ \\
\hline Corn grain & 53.09 & 61.96 \\
\hline Soybean meal (46\% CP) & 37.63 & 30.77 \\
\hline Soybean oil & 3.10 & 3.31 \\
\hline Dicalcium phosphate & 1.94 & 1.65 \\
\hline Calcitic limestone & 0.93 & 0.85 \\
\hline Salt & 0.41 & 0.37 \\
\hline DL-methionine & 0.36 & 0.23 \\
\hline L-lysine $\mathrm{HCl}$ & 0.33 & 0.20 \\
\hline Sodium bicarbonate & 0.15 & 0.15 \\
\hline L-threonine & 0.14 & 0.05 \\
\hline Choline chloride & 0.05 & 0.05 \\
\hline Mineral and vitamin supplement (no Zn $)^{1}$ & 0.40 & 0.40 \\
\hline Butyl-Hydroxy-Toluene (BHT) & 0.01 & 0.01 \\
\hline Inert material & 1.46 & - \\
\hline Total & 100.00 & 100.00 \\
\hline \multicolumn{3}{|l|}{ Calculated and analysis results (\%)* } \\
\hline Metabolizable energy (Mcal/kg) & 2.95 & 3.10 \\
\hline Crude protein & 22.04 & 19.41 \\
\hline Ether extract & 5.59 & 6.02 \\
\hline Calcium & 0.94 & 0.82 \\
\hline Available phosphorus & 0.47 & 0.41 \\
\hline Sodium & 0.22 & 0.20 \\
\hline Chlorine & 0.29 & 0.26 \\
\hline Potassium & 0.84 & 0.74 \\
\hline Digestible lysine & 1.33 & 1.07 \\
\hline Digestible methionine + cystine & 0.94 & 0.77 \\
\hline Digestible methionine & 0.66 & 0.51 \\
\hline Digestible threonine & 0.86 & 0.70 \\
\hline Digdigestible tryptophan & 0.24 & 0.21 \\
\hline Zinc $(\mathrm{mg} / \mathrm{kg})$ & 33.00 & 31.75 \\
\hline
\end{tabular}

${ }^{1}$ Mineral -vitamin supplement (no Zn). Guaranteed levels per kg product: Iron: 12.50g; manganese: 17.50g; Zinc: 0.00g; Copper: 2,000mg; lodine: 300mg; selenium: 50mg; VIT A: 1.750.000IU; VIT D3: 550.000IU, VIT E:2,750; VIT K3: 400mg; VIT B1: 500mg; VIT B2: 1,250mg; VIT B6: 750mg; VIT B12: 3,000mcg; choline: 78.12g; Niacin: 8,750mg; pantothenic acid: 3,250mg; folic acid: $200 \mathrm{mg}$; BHT: $25 \mathrm{~g}$; Virginiamycin: 2,500mg; Monensin: 25g.

*Only zinc was analysed and other nutrients and energy levels were calculated

Inorganic Mn) or manganese methionine (MnZinpro ${ }^{\circledR}$, containing 8\% Mn - Organic Mn), as shown in Table 4.

Dietary zinc (Table 5) and manganese (Table 6) levels were determined at Mineral Laboratory of the Faculty of Animal Science and Food Engineering (FZEA USP). Levels were analyzed by atomic absorption spectrophometry in a Perkin Elmer-AAS 100 device, according to the method of AOAC (1996).

Birds were offered feed and water ad libitum and were submitted to the same general management during the entire experimental period. A continuous lighting program (24 hours of light) was adopted for the entire experimental period. Air temperature and relative humidity were monitored using thermo- 
Faria Filho DE, Nakagi VS,

Kobashigawa EH, Caniatto ARM,

Faria DE, Pacheco BHC
Dietary Levels of Zinc and Manganese on the

Performance of Broilers Between 1 to 42 Days of Age
Table 2 - Ingredient composition of the experimental diets for the phases from 1 to 21 and from 22 to 42 days of age, without manganese supplementation (Experiment 2).

\begin{tabular}{|c|c|c|}
\hline \multirow[t]{2}{*}{ Ingredients } & \multicolumn{2}{|c|}{ Experimental phase (days) } \\
\hline & $1-21$ & $22-42$ \\
\hline Corn grain & 53.09 & 61.96 \\
\hline Soybean meal (46\% CP) & 37.63 & 30.77 \\
\hline Soybean oil1 & 3.10 & 3.31 \\
\hline Dicalcium phosphate & 1.94 & 1.65 \\
\hline Calcitic limestone & 0.93 & 0.85 \\
\hline Salt & 0.41 & 0.37 \\
\hline DL-methionine & 0.36 & 0.23 \\
\hline L-lysine $\mathrm{HCl}$ & 0.33 & 0.20 \\
\hline Sodium bicarbonate & 0.15 & 0.15 \\
\hline L-threonine & 0.14 & 0.05 \\
\hline Choline chloride & 0.05 & 0.05 \\
\hline Mineral and vitamin supplement (no Mn) ${ }^{1}$ & 0.40 & 0.40 \\
\hline Butyl-Hydroxy-Toluene (BHT) & 0.01 & 0.01 \\
\hline Inert material & 1.46 & - \\
\hline Total & 100.00 & 100.00 \\
\hline \multicolumn{3}{|l|}{ Calculated and analysis results (\%)* } \\
\hline Metabolizable energy (Mcal/kg) & 2.95 & 3.10 \\
\hline Crude protein & 22.04 & 19.41 \\
\hline Ether extract & 5.59 & 6.02 \\
\hline Calcium & 0.94 & 0.82 \\
\hline Available phosphorus & 0.47 & 0.41 \\
\hline Sodium & 0.22 & 0.20 \\
\hline Chlorine & 0.29 & 0.26 \\
\hline Potassium & 0.84 & 0.74 \\
\hline Digestible lysine & 1.33 & 1.07 \\
\hline Digestible methionine + cystine & 0.94 & 0.77 \\
\hline Digestible methionine & 0.66 & 0.51 \\
\hline Digestible threonine & 0.86 & 0.70 \\
\hline Digestible tryptophan & 0.24 & 0.21 \\
\hline Manganese (mg/kg) & 37.80 & 34.90 \\
\hline
\end{tabular}

'Mineral -vitamin supplement (no Mn). Guaranteed levels per kg product: Iron: 12.50g; manganese: 00.00g; Zinc: $12.50 \mathrm{~g}$; Copper: 2,000mg; lodine: $300 \mathrm{mg}$; selenium: 50mg; VIT A: 1,750,000IU; VIT D3: 550,000IU, VIT E:2,750; VIT K3: 400mg; VIT B1: 500mg; VIT B2: 1,250mg; VIT B6: 750mg; VIT B12: 3,000mcg; choline: 78.12g; Niacin: 8,750mg; pantothenic acid: 8,750mg; folic acid: 200mg; BHT: 25g; Virginiamycin: 2,500mg; Monensin: 25g.

*Only manganese was analysed and other nutrients and energy levels were calculated

hygrometers place at intermediate battery height. The average temperatures (maximal and minimal) recorded during experiment 1 were $31.61 \pm 1.95^{\circ} \mathrm{C}$ and 24.43 $\pm 2.25^{\circ} \mathrm{C}$, respectively. Average recorded relative humidity values were $29.26 \pm 7.27 \%$ maximum and $22.20 \pm 3.47 \%$ minimum. The average temperatures (maximal and minimal) recorded during experiment 2 were $31.22 \pm 1.94^{\circ} \mathrm{C}$ and $24.75 \pm 2.06^{\circ} \mathrm{C}$, respectively. Average recorded relative humidity values were 45.20 $\pm 12.31 \%$ maximum and $32.75 \pm 9.98 \%$ minimum .
Table 3 - Description of the experimental diets of experiment 1 (Zinc)

\begin{tabular}{|c|c|c|}
\hline Treatments & Trace mineral & Inclusion level (mg/kg) \\
\hline 1 & No Zn & 0 \\
\hline 2 & Inorganic Zn & 60 \\
\hline 3 & Inorganic Zn & 100 \\
\hline 4 & Organic Zn & 20 \\
\hline 5 & Organic Zn & 40 \\
\hline 6 & Organic Zn & 60 \\
\hline 7 & Organic Zn & 80 \\
\hline 8 & Organic Zn & 100 \\
\hline
\end{tabular}

Table 4 - Description of the experimental diets of experiment 2 (Manganese)

\begin{tabular}{|c|c|c|}
\hline Treatments & Trace mineral & Inclusion level (mg/kg) \\
\hline 1 & No $\mathrm{Mn}$ & 0 \\
\hline 2 & Inorganic Mn & 65 \\
\hline 3 & Inorganic Mn & 105 \\
\hline 4 & Organic Mn & 25 \\
\hline 5 & Organic Mn & 45 \\
\hline 6 & Organic Mn & 65 \\
\hline 7 & Organic Mn & 85 \\
\hline 8 & Organic Mn & 105 \\
\hline
\end{tabular}

Table 5 - Analyzed Zinc content ( $\mathrm{mg} / \mathrm{kg}$ ) in the experimental diets

\begin{tabular}{lccc}
\hline Treatments & 21 days of age & 42 days of age \\
\cline { 1 - 1 } 2 & 33.00 & 31.75 \\
3 & 78.00 & 95.50 \\
4 & 153.00 & 126.00 \\
5 & 48.50 & 68.75 \\
6 & 89.75 & 85.00 \\
7 & 106.00 & 101.25 \\
8 & 136.75 & 137.00 \\
\hline
\end{tabular}

Table 6 - Analyzed Manganese content $(\mathrm{mg} / \mathrm{kg}$ ) in the experimental diets

\begin{tabular}{lccc}
\hline Treatments & 21 days of age & & 42 days of age \\
\cline { 1 - 1 } 2 & 37.80 & 34.90 \\
3 & 126.85 & 63.05 \\
4 & 133.65 & 103.15 \\
5 & 60.50 & 55.45 \\
6 & 76.25 & 63.35 \\
7 & 86.35 & 70.40 \\
8 & 123.75 & 83.90 \\
\hline
\end{tabular}

Birds were vaccinated at the hatchery against Marek's disease, and at hatch and 7 days of age, by eye drop, against Newcastle and Infectious Bursal diseases $\left(\right.$ Biovet $\left.^{\circledR}\right)$. 
Faria Filho DE, Nakagi VS,

Kobashigawa EH, Caniatto ARM,

Faria DE, Pacheco BHC
Dietary Levels of Zinc and Manganese on the

Performance of Broilers Between 1 to 42 Days of Age
Birds were weighed at the beginning of the experimental period and then weekly to determine weight gain. Feed intake was calculated subtracting feed residues in the feeder and feed waste in the trays from total amount of feed offered. Feed conversion ratio (FCR) was calculated as the ratio between feed intake and weight gain. Livability was calculated as the number of birds alive in the beginning of the experimental period minus the number of dead at the end of the period. Production efficiency index (PEI) was calculated according to the equation below.

$$
\mathrm{PEI}=[(\mathrm{DWG} \times \mathrm{L}) /(\mathrm{FCR} \times 10)]
$$

Where: $\quad$ DWG: daily weight gain (g);

L: livability (\%);

FCR: feed conversion ratio

On the first and the last day of the experimental period, water samples were collected from the drinker in plastic flasks provided by the Laboratório OIKOS Controle Ambiental Ltda., located in Pirassununga, SP, for the analyses of zinc and manganese water content. In experiment 1 the testing methodology used was Zincon Method and apparatus used was SMEWW
3500 ZnB. In experiment 2 the testing methodology used was Persulfate Method and apparatus used was SMEWW 3500 MnB.

Bird performance in both experiments was analyzed according to the slope-ratio method, as described by Sakomura \& Rostagno (2007). In experiment 1, the treatment without zinc was compared with two levels of inorganic zinc (60 and $100 \mathrm{mg} / \mathrm{kg}$ ) and two levels of organic zinc (60 and $100 \mathrm{mg} / \mathrm{kg}$ ). Zinc requirements were determined by comparing levels only of the organic zinc source, zinc methionine (20, $40,60,80$, and $100 \mathrm{mg} / \mathrm{kg}$ ). In experiment 2, the treatment without manganese was compared with two levels of inorganic manganese (65 and $105 \mathrm{mg} /$ $\mathrm{kg}$ ) and two levels of organic manganese (65 and 105 $\mathrm{mg} / \mathrm{kg}$ ). Manganese requirements were determined by comparing levels only of the organic manganese source, manganese methionine $(25,45,65,85$, and $105 \mathrm{mg} / \mathrm{kg}$ ).

The obtained results were submitted to analysis of variance for using statistical package SAS (2004) and means were compared by the test of Turkey at $5 \%$ probability level.

Table 7 - Performance characteristics of broilers in the periods from 1 to 21,22 to 42 , and from 1 to 42 days of age as influenced by dietary organic and inorganic zinc levels.

\begin{tabular}{|c|c|c|c|c|c|c|c|c|c|c|}
\hline \multirow{3}{*}{ Characteristic } & \multicolumn{8}{|c|}{ Zinc (mg/kg) } & \multirow{3}{*}{$\begin{array}{l}\text { CV } \\
(\%)\end{array}$} & \multirow{3}{*}{$\begin{array}{c}\text { Level of } \\
\text { significance }\end{array}$} \\
\hline & \multirow[b]{2}{*}{0} & \multicolumn{2}{|c|}{ Inorganic } & \multicolumn{5}{|c|}{ Organic } & & \\
\hline & & 60 & 100 & 20 & 40 & 60 & 80 & 100 & & \\
\hline \multicolumn{11}{|l|}{1 day of age } \\
\hline IW (g) & 45.20 & 45.20 & 45.20 & 45.20 & 45.20 & 45.20 & 45.00 & 45.60 & 1.97 & ns \\
\hline \multicolumn{11}{|c|}{$1-21$ days of age } \\
\hline BW (g) & 886.04 & 874.70 & 901.09 & 870.43 & 885.27 & 888.43 & 903.27 & 923.75 & 3.88 & ns \\
\hline $\mathrm{FI}(\mathrm{g})$ & 1145.57 & 1118.74 & 1144.36 & 1112.30 & 1151.01 & 1126.02 & 1125.18 & 1162.28 & 4.17 & ns \\
\hline WG (g) & 840.84 & 829.48 & 855.89 & 825.23 & 840.07 & 843.23 & 858.27 & 878.15 & 4.10 & ns \\
\hline FCR & 1.36 & 1.35 & 1.34 & 1.35 & 1.37 & 1.33 & 1.31 & 1.32 & 5.62 & ns \\
\hline L (\%) & 100.00 & 99.17 & 99.17 & 99.17 & 97.50 & 99.17 & 99.17 & 99.17 & 1.78 & ns \\
\hline \multicolumn{11}{|c|}{$22-42$ days of age } \\
\hline BW (g) & 2314.67 & 2398.74 & 2378.51 & 2397.57 & 2394.05 & 2359.68 & 2381.11 & 2434.70 & 5.75 & ns \\
\hline $\mathrm{FI}(\mathrm{g})$ & 2860.00 & 2963.87 & 2954.15 & 3028.97 & 3046.41 & 2908.51 & 2991.52 & 2977.03 & 4.08 & ns \\
\hline WG (g) & 1428.63 & 1524.04 & 1477.42 & 1527.14 & 1508.78 & 1471.25 & 1477.84 & 1510.95 & 4.91 & ns \\
\hline FCR & 2.00 & 1.94 & 2.00 & 1.98 & 2.02 & 1.98 & 2.02 & 1.97 & 7.59 & ns \\
\hline L (\%) & 100.00 & 100.00 & 98.89 & 98.89 & 98.89 & 100.00 & 97.78 & 98.89 & 2.03 & $\mathrm{~ns}$ \\
\hline \multicolumn{11}{|c|}{$1-42$ days of age } \\
\hline BW (g) & 2314.67 & 2398.74 & 2378.51 & 2397.57 & 2394.05 & 2359.68 & 2381.11 & 2434.70 & 5.75 & ns \\
\hline $\mathrm{FI}(\mathrm{g})$ & 4005.57 & 4082.61 & 4098.51 & 4141.27 & 4197.42 & 4034.53 & 4116.70 & 4139.31 & 4.53 & ns \\
\hline WG (g) & 2269.47 & 2353.54 & 2333.31 & 2352.37 & 2348.85 & 2314.48 & 2336.11 & 2389.10 & 6.01 & ns \\
\hline FCR & 1.76 & 1.73 & 1.76 & 1.76 & 1.79 & 1.74 & 1.76 & 1.73 & 3.98 & ns \\
\hline L (\%) & 100.00 & 99.58 & 99.03 & 99.03 & 98.19 & 99.58 & 98.47 & 99.03 & 1.42 & ns \\
\hline PEI & 307 & 323 & 312 & 320 & 306 & 315 & 311 & 326 & 5.87 & ns \\
\hline
\end{tabular}

IW (g) - initial weight; BW (g) - body weight; Fl (g) - feed intake; WG (g) - weight gain; FCR - feed conversion ratio; L (\%) - livability; PEl - production efficiency index.

CV $(\%)$ - coefficient of variation; ns - non-significant effect. 


\section{RESULTS AND DISCUSSION}

The results of experiment 1 did not show any influence of zinc levels ( $p>0.05)$ on the performance characteristics (feed intake, body weight, feed conversion ratio, weight gain or livability) that were weekly evaluated during the periods from 1 to 7,8 to 14,15 to 21,22 to 28,29 to 35 , and 36 to 42 days of age (data not shown) and the periods from 1 to 21 and 22 to 42 and the total experimental period from 1 to 42 days (Table7). Similar results were obtained by Gomes et al. (2009), Huang et al. (2009), Bun et al. (2011), Salim et al. (2012), Yalcinkaya et al. (2012), Sunder et al. (2013) and Vieira et al. (2013).

On the other hand, Swinkel et al. (1994) found that diets with low zinc levels resulted in low feed intake, whereas Burrell et al. (2004), adding graded zinc levels to the basal diet significantly increased broiler weight gain, but not observe any changes in feed conversion ratio or mortality.

The optimal weight gain was obtained at $80 \mathrm{mg}$ of $\mathrm{Zn} / \mathrm{kg}$, exceeding the recommendations of Rostagno et al. (2005) of $60 \mathrm{mg} / \mathrm{kg}$. The results of the present experiment, however, do not suggest that zinc levels limited feed intake or weight gain. The reasons for the similarities and or differences presented the results may be due to the creation of the birds system metal $x$ floor batteries, type of inorganic and organic trace mineral, concentration of trace minerals and studied strain of the bird.

There was no significant effect ( $p>0.05)$ of zinc levels on the production efficiency index of broilers at 42 days of age (Table 7). In the study of Gomes et al. (2009), because zinc levels and sources (organic and inorganic) did not affect the most important economic characteristics (weight gain, feed intake, and feed conversion ratio), the authors concluded that zinc levels of 25 to $30 \mathrm{mg} / \mathrm{kg}$, typically present in practical diets based on corn and soybean meal, are sufficient to supply the requirements of broilers from 1 to 42 days.

Although no effect of zinc source was observed in experiment 1, Kiefer (2005) mention promising results with the use of chelated trace minerals, despite the lack of differences in the responses when the highest inorganic trace mineral concentration is supplied. The higher bioavailability of chelated trace minerals allows

Table 8 - Performance characteristics of broilers in the periods from 1 to 21,22 to 42 , and from 1 to 42 days of age as influenced by dietary manganese source and level.

\begin{tabular}{|c|c|c|c|c|c|c|c|}
\hline \multirow{3}{*}{ Characteristic } & \multicolumn{5}{|c|}{ Manganese (mg/kg) } & \multirow{3}{*}{ CV (\%) } & \multirow{3}{*}{ p Value } \\
\hline & \multirow[b]{2}{*}{0} & \multicolumn{2}{|c|}{ Inorganic } & \multicolumn{2}{|c|}{ Organic } & & \\
\hline & & 65 & 105 & 65 & 105 & & \\
\hline \multicolumn{8}{|l|}{1 day of age } \\
\hline IW (g) & 45.55 & 46.05 & 45.43 & 46.80 & 45.15 & 2.25 & ns \\
\hline \multicolumn{8}{|c|}{$1-21$ days of age } \\
\hline $\mathrm{BW}(\mathrm{g})$ & 877.29 & 860.57 & 933.59 & 916.55 & 902.41 & 4.63 & ns \\
\hline $\mathrm{FI}(\mathrm{g})$ & 1094.46 & 1068.35 & 1129.60 & 1128.53 & 1113.98 & 4.49 & ns \\
\hline WG (g) & 831.74 & 814.52 & 878.15 & 869.75 & 857.26 & 4.73 & ns \\
\hline FCR & 1.31 & 1.31 & 1.29 & 1.30 & 1.30 & 4.94 & ns \\
\hline$L(\%)$ & 100.00 & 100.00 & 98.33 & 96.17 & 100.00 & 1.11 & ns \\
\hline \multicolumn{8}{|c|}{$22-42$ days of age } \\
\hline $\mathrm{BW}(\mathrm{g})$ & 2338.45 & 2438.30 & 2445.79 & 2394.88 & 2436.28 & 4.15 & ns \\
\hline $\mathrm{FI}(\mathrm{g})$ & 2742.11 & 2893.56 & 2845.24 & 2790.77 & 2821.04 & 4.91 & ns \\
\hline WG (g) & 1461.16 & 1567.55 & 1512.28 & 1478.33 & 1553.87 & 5.83 & ns \\
\hline FCR & 1.88 & 1.84 & 1.88 & 1.89 & 1.81 & 5.21 & ns \\
\hline$L(\%)$ & 97.78 & 96.67 & 98.89 & 100.00 & 98.89 & 2.50 & ns \\
\hline \multicolumn{8}{|c|}{$1-42$ days of age } \\
\hline $\mathrm{BW}(\mathrm{g})$ & 2338.45 & 2438.30 & 2445.79 & 2394.88 & 2436.28 & 4.15 & ns \\
\hline $\mathrm{FI}(\mathrm{g})$ & 3836.57 & 3961.91 & 3974.84 & 3920.31 & 3935.07 & 4.17 & ns \\
\hline WG (g) & 2292.97 & 2392.28 & 2420.43 & 2348.08 & 2411.28 & 4.22 & ns \\
\hline FCR & 1.67 & 1.66 & 1.64 & 1.67 & 1.63 & 3.38 & ns \\
\hline$L(\%)$ & 98.89 & 98.33 & 98.61 & 99.58 & 99.44 & 1.42 & ns \\
\hline PEI & 323 & 337 & 346 & 333 & 350 & 5.77 & ns \\
\hline
\end{tabular}

IW (g) - initial weight; BW (g) - body weight; FI (g) - feed intake; WG (g) - weight gain; FCR - feed conversion ratio; L (\%) - livability; PEl - production efficiency index. $\mathrm{CV}(\%)$ - coefficient of variation; ns - non-significant effect. 
Faria Filho DE, Nakagi VS,

Kobashigawa EH, Caniatto ARM,

Faria DE, Pacheco BHC
Dietary Levels of Zinc and Manganese on the

Performance of Broilers Between 1 to 42 Days of Age reducing their inclusion levels, thereby minimizing the possible environmental impact of animal waste. However, the use of chelated and organic sources is still limited due to their price, increasing the cost of dietary mineral supplementation (Kiefer, 2005).

The zinc levels of the diet without zinc supplementation in the present study were $33.00 \mathrm{mg} /$ $\mathrm{kg}$ and the $31.75 \mathrm{mg} / \mathrm{kg}$ when broilers were 21 and 42 days of age, respectively, and therefore were lower than those recommended by the NRC (1994), of 40 $\mathrm{mg} / \mathrm{kg}$; by Rostagno et al. (2005), of $60 \mathrm{mg} / \mathrm{kg}$; and by Rostagno et al. (2011) of $65 \mathrm{mg} / \mathrm{kg}$.

Previous reviews have provided no evidence for a consistent benefit from providing zinc as organic complexes rather than simple inorganic salts (Suttle, 2010).

The results of experiment 2 did not show any influence of manganese levels ( $p>0.05)$ on the performance characteristics (feed intake, body weight, feed conversion ratio, weight gain or livability) that were weekly evaluated during the periods from 1 to 7,8 to 14,15 to 21,22 to 28,29 to 35 , and 36 to 42 days of age (data not shown) and the periods of 1 to 21 and 22 to 42 and the total experimental period from 1 to
42 days (Tables 8 and 9). Similar results were obtained by Cupertino et al. (2005), Sunder et al. (2006) and Sunder et al. (2013) also did not observe any effect of manganese levels on broiler performance.

There was an effect $(p<0.001)$ of organic manganese levels on the production efficiency index of 42 days of age broilers, and the best results were obtained by those birds fed with 45, 65, and $105 \mathrm{mg} /$ $\mathrm{kg}$ (Table 9). The results also show that diets based on corn and soybean meal allow broilers to express their maximal genetic potential. According to Cupertino et al. (2005), the fact that the tested manganese levels and sources (organic and inorganic) did not influence the economically important parameters (weight gain, feed intake, and feed conversion ratio) suggests that the levels from 30 to $40 \mathrm{mg} / \mathrm{kg}$, typically present in the diets, are sufficient to allow broiler growth. Southern \& Baker (1983), and Cupertino et al. (2005) reported that manganese influenced broiler performance only when very high levels, promoting toxicity symptoms, were used, or according to Cupertino et al.(2005), when there was severed efficiency caused by purified diets.

In the present study, manganese levels determined in basal starter and grower diets were $37.80 \mathrm{mg} / \mathrm{kg}$

Table 9 - Performance characteristics of broilers in the periods of 1 to 21,22 to 42 , and from 1 to 42 days of age as influenced by dietary organic manganese.

\begin{tabular}{|c|c|c|c|c|c|c|c|}
\hline \multirow[t]{2}{*}{ Characteristic } & \multicolumn{5}{|c|}{ Organic manganese $(\mathrm{mg} / \mathrm{kg})$} & \multirow[t]{2}{*}{ CV (\%) } & \multirow[t]{2}{*}{ p Value } \\
\hline & 25 & 45 & 65 & 85 & 105 & & \\
\hline \multicolumn{8}{|l|}{1 day of age } \\
\hline IW (g) & 45.10 & 45.75 & 46.80 & 46.05 & 45.15 & 2.25 & ns \\
\hline \multicolumn{8}{|c|}{$1-21$ days of age } \\
\hline BW (g) & 859.06 & 875.46 & 916.55 & 873.80 & 902.41 & 4.63 & ns \\
\hline $\mathrm{Fl}(\mathrm{g})$ & 1088.71 & 1093.33 & 1128.53 & 1116.31 & 1113.98 & 4.49 & ns \\
\hline WG (g) & 813.96 & 829.71 & 869.75 & 837.75 & 857.26 & 4.73 & ns \\
\hline $\mathrm{FCR}(\mathrm{g})$ & 1.34 & 1.32 & 1.30 & 1.37 & 1.30 & 4.94 & ns \\
\hline$L(\%)$ & 100.00 & 100.00 & 96.17 & 100.00 & 100.00 & 1.11 & ns \\
\hline \multicolumn{8}{|c|}{$22-42$ days of age } \\
\hline BW (g) & 2341.03 & 2357.99 & 2394.88 & 2349.68 & 2436.28 & 4.15 & ns \\
\hline $\mathrm{Fl}(\mathrm{g})$ & 2772.42 & 2733.40 & 2790.77 & 2749.00 & 2821.04 & 4.91 & ns \\
\hline WG (g) & 1481.97 & 1482.53 & 1478.33 & 1465.88 & 1553.87 & 5.83 & ns \\
\hline $\mathrm{FCR}(\mathrm{g})$ & 1.87 & 1.84 & 1.89 & 1.87 & 1.81 & 5.21 & ns \\
\hline L (\%) & 100.00 & 100.00 & 100.00 & 100.00 & 98.89 & 2.50 & ns \\
\hline \multicolumn{8}{|c|}{$1-42$ days of age } \\
\hline BW (g) & 2341.03 & 2357.99 & 2394.88 & 2349.68 & 2436.28 & 4.15 & ns \\
\hline $\mathrm{Fl}(\mathrm{g})$ & 3861.17 & 3817.70 & 3920.31 & 3885.35 & 3935.07 & 4.17 & ns \\
\hline WG (g) & 2296.01 & 2312.30 & 2348.08 & 2303.67 & 2411.28 & 4.22 & ns \\
\hline $\mathrm{FCR}(\mathrm{g} / \mathrm{g})$ & 1.68 & 1.65 & 1.67 & 1.69 & 1.63 & 3.38 & ns \\
\hline L (\%) & 100.00 & 100.00 & 99.58 & 100.00 & 99.44 & 1.42 & ns \\
\hline PEI & $326 b$ & 333ab & 334ab & $325 b$ & $350 a$ & 2.55 & 0.001 \\
\hline
\end{tabular}

IW (g) - initial weight; BW (g) - body weight; FI (g) - feed intake; WG (g) - weight gain; FCR (g) - feed conversion ratio; L (\%) - livability; PEI - production efficiency index.

CV (\%) - coefficient of variation; ns - non-significant effect. 
Faria Filho DE, Nakagi VS,

Kobashigawa EH, Caniatto ARM,

Faria DE, Pacheco BHC
Dietary Levels of Zinc and Manganese on the

Performance of Broilers Between 1 to 42 Days of Age and $34.90 \mathrm{mg} / \mathrm{kg}$, respectively, which are lower than those recommended by the NRC (1994), of $60 \mathrm{mg} /$ $\mathrm{kg}$; by Rostagno et al. (2005), of $65 \mathrm{mg} / \mathrm{kg}$; and by Rostagno et al. (2011) of $70 \mathrm{mg} / \mathrm{kg}$.

In the period from 2000 to 2010 have seen a flurry of publications on the merits of organic sources of manganese. However, the results are hard to interpret because of the wide variety of complexes tested, the unusual circumstances of some tests and the variety of responses used in the tests. The addition of organic manganese sources to the diet of poultry is unlikely to improve health or production when compared with an inorganic salt or oxide. Previous research and development resources should no longer be wasted in chasing trivial advantages for manganese chelates (Suttle, 2010).

\section{WATER ANALYSIS}

The zinc and manganese levels in the water samples collected on day 1 (sample 1) and on day 42 (sample 2) of the experimental period are shown in Tables 10 and 11. In experiment 1, the Zinc on Method was applied using SMEWW $3500 \mathrm{ZnB}$. In experiment 2, the Persulfate Method was applied using the device SMEWW 3500 MnB.

Table 10 - Zinc level in the water samples

\begin{tabular}{llll}
\hline Samples & Unit & MQL & Content \\
\hline 1 & $\mathrm{mg} / \mathrm{L}$ & 0.05 & $<0.05$ \\
2 & $\mathrm{mg} / \mathrm{L}$ & 0.05 & 0.018 \\
\hline
\end{tabular}

MQL Method quantification limit

Table 11 - Manganese content in the water samples

\begin{tabular}{llll}
\hline Samples & Unit & MQL & Content \\
\hline 1 & $\mathrm{mg} / \mathrm{L}$ & 0.007 & 0.062 \\
2 & $\mathrm{mg} / \mathrm{L}$ & 0.007 & 0.030 \\
\hline
\end{tabular}

MQL Method quantification limit

According to Regulation n. 2.914, of December 12, 2011, the maximum allowed for zinc and manganese are $5 \mathrm{mg} / \mathrm{L}$ and $0.1 \mathrm{mg} / \mathrm{L}$, respectively, in the drinkability table (Brazil, 2011). The samples of the water offered to the broilers presented zinc and manganese levels below the MQL, and therefore, it was considered that they not influence the levels of these trace minerals offered to the birds. The conditions of this study, the results do not interfere in the analyzed characteristics and water used are normal.

\section{CONCLUSIONS}

It was concluded that the requirements of zinc and manganese of broilers from 1 to 42 days of age were supplied without addition of zinc or manganese, under the conditions of the present experiments. However, under commercial rearing conditions, which are more challenging, the use of levels higher than $33.00 \mathrm{mg} / \mathrm{kg}$ and $37.80 \mathrm{mg} / \mathrm{kg}$ of zinc and manganese, respectively, may be justified.

\section{REFERENCES}

Aksu DS, Aksu T, Önel SE. Does inclusion at low levels of organically complexed minerals versus inorganic forms create a weakness in performance or antioxidant defense system in broiler diets? International Journal of Poultry Science 2012;11(10):666-672.

AOAC - Association of Official Analytical Chemists. Official methods of analysis. 11th ed. Washington: Association of Official Analytical Chemists;1996. 1051p.

Brasil. Portaria n².914, de 12 de dezembro de 2011. Diário Oficial da União, Brasília, DF, 14 dez. 2011. Seção I, p.39 a 46.

Bun SD, Guo YM, Guo FC, Ji FJ, Cao H. Influence of organic zinc supplementation on the antioxidant status and immune responses of broilers challenged with Eimeriatenella. Poultry Science 2011;90(6):1220-1226.

Burrell AL, Dozier WA, Davisa AJ, Comptona MM, Freemana ME, Vendrell $\mathrm{PF}$, et al. Responses of broilers to dietary zinc concentrations and sources in relation to environmental implications. British Poultry Science 2004; $45(2): 255-263$.

Cupertino ES, Gomes PC, Teixeira LF. Exigências de manganês para frangos de corte nas fases de crescimento e terminação. Revista Brasileira de Zootecnia 2005;34(6):2308-2315.

Gomes PC, Rigueira DCM, Brumano G, Albino LFT, Rostagno HS, Schimdt M. Níveis nutricionais de zinco para frangos de corte machos e fêmeas nas fases de crescimento e terminação. Revista Brasileira de Zootecnia 2009;38(9):1719-1725.

Kiefer C. Minerais quelatados na nutrição de aves e suínos. Revista Eletrônica Nutritime 2005;2(3):206-220.

NRC - National Research Council. Nutrient requirements of poultry. 9th ed. Washington: National Academy Press; 1994. 155p.

Rostagno HS, Albino LFTA, Donzele JL, Gomes PC, Oliveira RF, Lopes DC, et al. Tabelas brasileiras para aves e suínos: composição de alimentos e exigências nutricionais. $3^{a}$ ed. Viçosa: UFV; 2011. 252p.

Rostagno HS, Albino LFTA, Donzele JL, Gomes PC, Oliveira RF, Lopes DC, et al. Tabelas brasileiras para aves e suínos: composição de alimentos e exigências nutricionais. $2^{a}$ ed. Viçosa: UFV; 2005. 186p.

Sakomura NK, Rostagno HS. Métodos de pesquisa em nutrição de monogástricos. Jaboticabal: Funep, 2007. 283p.

Salim HM, Lee HR, Jo C, Lee SK, Lee BD. Effect of sex and dietary organic zinc on growth performance, carcass traits, tissue mineral content, and blood parameters of broiler chickens. Biological Trace Element Research 2012;147(1/3):120-129.

SAS - Statistical Analyses System. User's guide: statistic. 12thed. New York: Scott \& Associates; 2004. 1686p.

Southern LL, Baker DH. Excess manganese ingestion in the chick. Poultry Science 1983;62:642-646, 1983.

Sunder GS, Kumar CV, Panda AK, Raju MVLN, Rao R. Effect of supplemental organic $\mathrm{Zn}$ and $\mathrm{Mn}$ on broiler performance, bone measures, tissue mineral uptake and immune response at 35 days of age. Poultry Science 2013;3(1):1-11. 
Faria Filho DE, Nakagi VS,

Kobashigawa EH, Caniatto ARM,

Faria DE, Pacheco BHC
Dietary Levels of Zinc and Manganese on the

Performance of Broilers Between 1 to 42 Days of Age

Vieira MM, Ribeiro AML, Kessler AM, Moraes ML, Kunrath MA, Ledur VS. Different sources of dietary zinc for broilers submitted to immunological, nutritional, and environmental challenge. The Journal of Applied Poultry Research 2013;22:855-861.

Yalcinkaya I, Cinar M, Yildirim E, Erat S, Basalan M, Gungor T. The effect of prebiotic and organic zinc alone and in combination in broiler diets on the performance and some blood parameters. Italian Journal of Animal Science 2012;11:298-302.

Świątkiewicz S, Arczewska-Włosek A, Józefiak, D. The efficacy of organic minerals in poultry nutrition: review and implications of recent studies. World's Poultry Science Journal 2014;70(3):475-486.

Swinkels JW, Kornegay ET, Verstegen MW. Biology of zinc and biological value of dietary organic zinc complexes and chelates. Nutrition Research Reviews 1994;7:129-149. 